\title{
Ceviz gövde kanseri hastalığı etmeni Botryosphaeria dothidea'nın tanılanması ve bazı fungisitlerin hastalık etmenine karşı in vitro antifungal etkinliklerinin belirlenmesi
}

Identification of walnut stem canker disease agent Botryosphaeria dothidea and determination of in vitro antifungal efficiencies of some fungicides against the disease agent

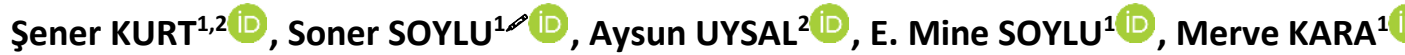 \\ ${ }^{1}$ Hatay Mustafa Kemal University, Faculty of Agriculture, Department of Plant Protection, Antakya-Hatay, Turkey. \\ ${ }^{2}$ Hatay Mustafa Kemal University, Centre for Implementation and Research of Plant Health Clinic, Antakya-Hatay, Turkey.
}

MAKALE BILGISI / ARTICLE INFO

Makale tarihçesi / Article history:

DOI: $10.37908 /$ mkutbd.686111

Geliş tarihi /Received:07.02.2020

Kabul tarihi/Accepted:28.02.2020

\section{Keywords:}

Walnut, Fungucides, Botryosphaeria dothidea, Botryosphaeriaceae.

\footnotetext{
Corresponding author: Soner SOYLU

凹: soylu@mku.edu.tr
}

\section{ÖZET / ABSTRACT}

\begin{abstract}
Aims: Symptoms of canker disease on walnut trees included brown to dark brown discoloration of vascular tissues, wood necrosis, and branch dieback were observed in several orchards in İskenderun City of Hatay Province in May 2018. The aims of this study were to identify the fungal pathogen and to determine its sensitivities against some fungicides.

Methods and Results: Isolations were made from diseased branches, cankers and asymptomatic walnut samples and causal disease agent was identified as Botryosphaeria dothidea based on morphological characteristics and molecular techniques. Pathogenicity tests showed that fungal isolate were highly virulent on shoots of walnut (cv. Chandler) trees commonly grown in the region. To our knowledge, this is the first report of Botryosphaeria dothidea infecting walnut in Turkey. In vitro antifungal effect of different concentrations of six fungicides, fluazinam (0.001-0.015 $\mu \mathrm{g} / \mathrm{ml})$, thiophanate-methyl (0.1-10.0), boscalid + pyraclostrobin (1.0-50.0 $\mu \mathrm{g} / \mathrm{ml})$, trifloxystrobin $(0.5-50.0 \mu \mathrm{g} / \mathrm{ml})$, kresoxim-methyl (0.1-50.0), and tebuconazole $(0.5-50.0 \mu \mathrm{g} / \mathrm{ml})$ were also evaluated against the pathogen. The mean effective concentration $\left(E_{50}\right)$ values were determined by Probit analysis. According to $\mathrm{EC}_{50}$ values, fluazinam $(0.002 \mu \mathrm{g} / \mathrm{ml})$ was recorded as the most effective fungicide and it was followed by thiophanate-methyl $(0.275 \mu \mathrm{g} / \mathrm{ml})$, tebuconazole $(0.994 \mu \mathrm{g} / \mathrm{ml})$, boscalid + pyraclostrobin $(3.993 \mu \mathrm{g} / \mathrm{ml})$ and trifloxystrobin $(4.262 \mu \mathrm{g} / \mathrm{ml})$. The lowest antifungal efficacy was followed by kresoxim-methly inhibiting mycelial growth by $37.5 \%$ at the highest concentration used.

Conclusions: To our knowledge, this is the first report of Botryosphaeria dothidea causing stem canker diseases on walnut trees grown in Turkey. Our results also suggest that the walnut canker disease caused by Botryosphaeria dothidea could be reduced effectively with the application of selected fungicides.

Significance and Impact of the Study: In conclusion, our results suggest that fluazinam, thiophanate-methyl and tebuconazole have the potential effects to control Botryosphaeria dothidea.
\end{abstract}

Atıf / Citation: Kurt Ş, Soylu S, Uysal A, Soylu EM, Kara M (2020) Ceviz gövde kanseri hastalığı etmeni Botryosphaeria dothidea'nın tanılanması ve bazı fungisitlerin hastalık etmenine karşı in vitro antifungal etkinliklerinin belirlenmesi. MKU. Tar. Bil. Derg. 25(1) : 46-56. DOI: 10.37908/mkutbd.686111 


\section{GíRiş}

İnsanların sağlıklı beslenme konusunda bilinçlenmesinin bir sonucu olarak günümüzde kabuklu meyvelere olan ilgisi de giderek artmaktadır. Odunsu bir ağaç türü olan cevizin, tohumları yüksek besin içeriğine ve ekonomik değere sahiptir. Özellikle proteinler ve esansiyel yağ asitleri açısından önemli bir besin kaynağıdır. Siyah ceviz (Juglans nigra) ve İngiliz cevizi (J. regia), dünya genelinde en yaygın tarımı yapılan ceviz türleridir. Siyah ceviz lezzetli olmasının yanında, sert kabuğu ve kabuğunun parçalanma zorluğu nedeniyle ticari olarak yetiştirilmemektedir. Ticari olarak üretilen ceviz çeşitlerinin neredeyse tümü İngiliz cevizinin melezleridir (Boriss ve ark., 2006). Dünya çapında ceviz üretimi son yıllarda hızla artmakta olup, 2017 yılında dünyanın en büyük kabuklu ceviz üreticisi ülkesi 489,866 ha alanda $1,925,403$ ton üretimi ile Çin olup, bu ülkeyi 135,570 ha'da 571,526 ton ile ABD, 53,952 ha'da 349,192 ton ile İran takip etmekte ve Türkiye, 87,670 ha alanda toplam 210,000 ton ile dünyada en fazla ceviz üreten 4. ülke pozisyonundadır (Anonim, 2017). Hatay ili genelinde ceviz üretim alanları gün geçtikçe genişlemekte olup, 2018 yılı itibariyle il genelinde 2,123 ton üretim gerçekleştirilmiştir (Anonim, 2018).

Ekim alanları günden güne genişleyen ceviz yetiştiriciliği ve üretimi, son yıllarda abiyotik ve biyotik etmenler tarafından etkilenmektedir. Botryosphaeriaceae familyasına ait fungal etmenler, dünya çapında geniş konukçu dağılışı göstermekte ve çok çeşitli odunsu meyve ağaçlarında değişik hastalıklara sebep olmaktadır (Barr, 1987; Slippers ve Wingfield, 2007). Bu familyaya ait fungal türlerin dünya çapında yetiştiriciliği yapılan badem, avokado, asma, zeytin ve fıstık gibi birçok önemli meyve ağacında yıkıcı hastalıklara sebep olduğu bildirilmiştir (Michailides, 1991; Ma ve Michailides, 2002; Úrbez-Torres ve ark., 2006; McDonald ve ark., 2009; Úrbez-Torres ve ark., 2009; Inderbitzin ve ark., 2010; Moral ve ark., 2010; McDonald ve Eskalen, 2011; ÚrbezTorres ve ark., 2013; Chen ve ark., 2014). ABD'nin California eyaletinde yetiştiriciliği yapılan İngiliz cevizini de içeren ceviz çeşitlerinde gövde kanseri, geriye doğru ölüm, sürgün, yaprak ve meyve yanıklıkları gibi hastalık belirtilerinin Botryosphaeria ve Diaporthe cinsine bağlı türler tarafından oluşturulduğu belirlenmiştir (Chen ve ark., 2014). Ülkemizde yetiştiriciliği yapılan ceviz ağaçlarında Botryosphaeriaceae familyasına ait türlerin neden olduğu hastalıklarla ilgili araştırmalar çok sınırlıdır. Ülkemizde Derviş ve ark. (2019) tarafından yakın zamanda yapılan bir çalışmada, Şanlıurfa ilinde yetiştiriciliği yapılan ceviz alanlarında Neoscytalidium dimidiatum'un kurumalar şeklinde hastalık belirtilerine neden olduğuna dair ilk kayıt bildirimi yapıımıştır.

Hatay ilinde ceviz üretilen alanların genişlemesi ile birlikte yetiştiriciler tarafından farklı hastalıklara ait şikayetler de artmaya başlamış olup 2019 yılında, Hatay ilinin i̇skenderun ilçesinde ceviz ağaçlarında Botryosphaeriaceae tür(ler)ince sebep olduğu düşünülen dal kanseri, geriye doğru ölüm şeklinde hastalık belirtileri gözlenmiştir.

Bu çalışmanın amacı, bölgede yetiştiriciliği yapılan ceviz ağaçlarının gövde, dalları ve meyvelerinde hastalığa neden olan olası hastalık etmeni tür(ler)ini morfolojik, moleküler ve patojenik olarak tanılamak ve yaygın olarak tespit edilen etmenin farklı kimyasal yapılardaki fungisitlere karşı duyarlııı̆ını belirlemektir.

\section{MATERYAL ve YÖNTEM}

\section{Hastalık etmeninin izolasyonu}

Hatay ilinin İskenderun ilçesinde yaygın olarak yetiştiriciliği yapılan Chandler çeşidi 5 farklı ceviz bahçesindeki enfekteli ağaç gövdelerinde gözlenen kanser belirtilerinden doku örnekleri alınarak plastik torbalar içerisinde laboratuvara getirilmiştir. Enfeksiyon sonucu meydana gelen nekrotik ve sağlam dokuları içeren, 3-4 mm büyüklüğündeki bitki kesitleri, \%2'lik $\mathrm{NaOCl}$ 'de 4 dakika yüzeyden dezenfekte edilmiş, $2 \mathrm{kez}$ steril distile suda durulandıktan sonra steril kurutma kağıtlarında kurumaya bırakılmıştır. Dezenfekte edilen bitki dokuları, $50 \mu \mathrm{g} / \mathrm{ml}$ oranında streptomisin sülfat içeren patates dekstroz agar (PDA) besi ortamına aktarılmıştır. PDA içeren petriler, $25^{\circ} \mathrm{C}^{\prime}$ de karanlıkta 5 gün süreyle inkübe edilmiş ve dokularda gelişen fungal kolonilerin uç kısmından alınan miselyal yapılar, aynı ortamı içeren yeni besi yerlerine aktarmak suretiyle saflaştırılmıştır. Tanılama ve fungisit etkinliğinin belirlendiği çalışmalarda tek spordan geliştirilmiş kültürler kullanılmıştır.

\section{Patojenisite çalışmaları}

Tipik hastalık belirtisi gösteren dokulardan yapılan izolasyon sonucu PDA besi yerinde gelişen fungus izolatlarından tek spor kültürleri elde edilmiş olup, tüm izolatlar sağlıklı ceviz fidanlarından kesilen $1.5-2 \mathrm{~cm}$ çaplı ve $20 \mathrm{~cm}$ uzunluğundaki sağlıklı dallara laboratuvarda önceden bildirildiği şekilde inoküle edilmiştir (Arzanlou ve ark. 2012). Inokülasyon yapılacak olan dallar \%0.5'lik sodyum hipokloritte 15 dakika süre ile bekletilerek yüzeyden dezenfekte edildikten sonra, saf su ile durulanmıştır. Öte yandan PDA' da geliştirilmiş olan 7 günlük fungal kültürlerden alınan miselyal diskler, sürgün üzerinde açılan $5 \mathrm{~mm}$ çapındaki yara dokusuna 
yerleştirilmiştir. Her bir sağlıklı ceviz sürgününün 3 farklı noktasında inokulasyonlar gerçekleştirilmiştir. Kontrol olarak ise sürgünlerdeki inokülasyon noktasına misel içermeyen agar diskler yerleştirilmiştir. Daha sonra inokülasyon alanları parafilmle sarılarak dal ve sürgünler, içerisinde steril nemli kurutma kağıtları bulunan 10 litrelik saklama kaplarında inkübasyona bırakılmıştır. Oda sıcaklığında bekletilen, patojenle inokule edilmiş ve patojen inokulasyonu yapılmamış kontrol uygulamaları, inokülasyondan 20 gün sonra odun dokularda oluşan lezyon uzunlukları yönünden değerlendirilmiştir (Damm ve ark., 2007; Nouri ve ark., 2019). Hastalık etmeni fungus, belirti gözlenen inokulasyon yerlerinden tekrar izole edilmiş ve orjinal izolatla benzer yapıda olup olmadığı teyit edilmek suretiyle Koch postulatı tamamlanmıştır.

\section{Hastalık etmeninin morfolojik karakterizasyonu}

İzolasyon sonucu elde edilen izolatlar morfolojik parametreler yönünden (koloni rengi, misel gelişimleri, piknid oluşumu, konidi şekil ve boyutları) PDA besi ortamında değerlendirilmiştir. Fungal izolatların konidi boyutları trinoküler araştırma mikroskobunda (NIKON Eclipse, Floresan ve DIC Ataçmanlı) ölçülerek fotoğraflanmıştır (Li ve ark., 2016). Fungal etmenin miselyal gelişimleri ve morfo-kültürel tanılama çalışmaları kapsamında V8 juice agar, czapek-dox agar (CDA), patates dekstroz agar (PDA), malt ekstrakt agar (MEA) ve su agarı (WA) besi ortamlarında sekiz farklı sıcaklık değerlerinde $\left(5,10,15,20,25,30,35,40^{\circ} \mathrm{C}\right)$ araştırılmıştır.

\section{Hastalık etmeninin moleküler karakterizasyonu}

Morfol Morfolojik olarak ön teşhisleri yapılmış izolatlara patojenisite testleri uygulanmış ve hastalık belirtilerinden geri izole edilen izolatın besi ortamında gelişen tek spor kültürlerinden alınan misellerinden (100 $\mathrm{mg}$ ) toplam genomik DNA izolasyonu, DNeasy Plant Mini Kiti (Qiagen, GeneMark Teknoloji Co, Valencia, CA, Katalog No. 69104) ile üretici firmanın önerdiği protokoller kullanılarak yürütülmüştür. PCR çalışmaları internal transcribed spacers (ITS) rDNA bölgesi ITS4 (5'TCCTCCGCTTATTGATATGC- $\left.3^{\prime}\right)$ ve ITS5 (5'GGAAGTAAAAGTCGTAACAAGG-3') primer çifti (White ve ark., 1990) ile $\beta$-tubulin (TUB2) gen bölgesi ise Bt2a ( $5^{\prime}$ GGTAACCAAATCGGTGCTGCTTTC- $\left.3^{\prime}\right)$ ve Bt2b (5'ACCCTCAGTGTAGTGACCCTTGGC-3') primer çifti (Glass ve Donaldson, 1995) kullanılmak suretiyle gerçekleştirilmiştir. DNA amplifikasyonunda; her bir reaksiyon için $5 \mu \mathrm{l}$ 10x enzim buffer, $10 \mathrm{mM}$ dNTP, 50 $\mathrm{mM} \mathrm{MgCl} 2,0.5 \mu \mathrm{l}$ primer, $0.2 \mu \mathrm{l}$ Taq DNA polimeraz ve 2 $\mu$ I DNA ile toplam $50 \mu$ l olacak şekilde üzeri su ile tamamlanmıştır. PCR amplifikasyon koşulları için, $95^{\circ} \mathrm{C}^{\prime}$ de $3 \mathrm{dk}$ başlangıç denatürasyonu, $95^{\circ} \mathrm{C}^{\prime} \mathrm{de} 1 \mathrm{dk}$. denatürasyon, annealing sıcaklığı ITS için $54^{\circ} \mathrm{C}$, TUB2 için $58^{\circ} \mathrm{C}, 72^{\circ} \mathrm{C}^{\prime}$ de $45 \mathrm{sn}$. ve final adımı olarak $72^{\circ} \mathrm{C}^{\prime}$ de $10 \mathrm{dk}$. olarak belirlenmiştir. Elde edilen DNA bandların kalitesine göre seçilen PCR ürünlerinin dizileme işlemi yaptırılmıştır. PCR ürünlerine ait DNA nükleotid dizileri, NCBI (National Center for Biotechnology Information) kütüphanesinde yer alan BLASTn algoritmasını kullanarak (Boratyn ve ark., 2013) taranmak suretiyle kütüphanede kesin tür tanısı yapılmış mevcut fungal türler ile eşleştirilmiştir. Bu sonuçlara göre tanısı yapılan izolatların, NCBI Genbankası kütüphanesinden erişim numaraları alınmıştır. İolatlar arasındaki genetik akrabalığı gösteren dendrogram Maksimum likelihood yöntemi kullanılarak oluşturulmuş ve elde edilen filogenetik ağacın teyidi, 1,000 tekrarlı olarak (Bootstrap, p-distance, pairwise deletion) yapılmıştır (Kumar ve ark., 2016).

\section{Hastalık etmeninin in vitro koşullarda fungisitlere karşı duyarlıı̆ıııı belirlenmesi}

Hastalık etmeninin in vitro koşullarda farklı kimyasal yapılardaki fungisitlere karşı duyarlılığının belirlenmesinde kullanılan fungisitler, etken maddeleri ve formulasyon tipleri Çizelge $1^{\prime}$ de verilmiştir. Söz konusu fungisitlerin fungal misel gelişimlerine etkinliklerini belirlendiği çalışmalarda, $B$. dothidea'nın bölge izolatı olan WBd31 kullanılmıştır.

Çizelge 1. In vitro etkinlik denemelerinde kullanılan etken maddeler, ticari preparatları ve diğer özellikleri

\begin{tabular}{llll}
\hline Etken Madde ve Oranı & Ticari İsmi & Firma & Formulasyon \\
\hline Fluazinam (500g/l) & NANDO 500 & NUFARM & SC \\
Boscalid+ pyraclostrobin (\%26.7+\%6.7) & SIGNUM & BASF & WG \\
Trifloxystrobin (\%50) & TUGART & GÜNER & WG \\
Kresoxim-methyl (\%50) & CANDIT & BASF & WG \\
Thiophanate-methyl (\% 70) & SUMITOP & SUMI AGRO & WP \\
Tebuconazole (\%25) & FOLICUR 25 & BAYER & WP \\
\hline
\end{tabular}


Çalışmada yer alan fungisitlerin fungisidal etkinlikleri, farklı konsantrasyonları [fluazinam: 0.001, 0.003, 0.005, $0.007,0.01 \mu \mathrm{g} / \mathrm{ml}$; boscalid + pyraclostrobin: 1.0, 3.0, 5.0, 10.0, 20.0, $50.0 \mu \mathrm{g} / \mathrm{ml}$; trifloxystrobin: $0.5,1.0,5.0$, 10.0, $50.0 \mu \mathrm{g} / \mathrm{ml}$; kresoxim-methyl: 0.1, 0.5, 1.0, 5.0, 10.0 $\mu \mathrm{g} / \mathrm{ml}$; thiophanate methyl: $0.1,0.5,1.0,3.0,5.0 \mu \mathrm{g} / \mathrm{ml}$ ve tebuconazole: $0.5,1.0,10.0,50.0 \mu \mathrm{g} / \mathrm{ml}$ ] içeren PDA besi yerinde belirlenmiştir. Her bir fungisitin belirlenen konsantrasyonları, $50^{\circ} \mathrm{C}$ ye soğutulmuş steril PDA ortamına karıştırılmış ve petri kaplarına $(15 \times 100 \mathrm{~mm})$ dökülmüştür. Kontrol olarak herhangi bir fungisit içermeyen PDA besi yeri bulunan petriler kullanılmıştır. Farklı fungisit konsantrasyonu içeren besi yerlerinin merkezine, 5 günlük $B$. dothidea $\mathrm{WBd31}$ izolatına ait fungal koloninin kenarlarından kesilmiş $5 \mathrm{~mm}$ çapındaki miselyal diskler yerleştirilmiştir. İnoküle edilmiş tüm uygulama ve kontrol petrileri, karanlıkta $20^{\circ} \mathrm{C}^{\prime}$ de 3-7 gün süre ile inkübe edilmiştir. Bu süre boyunca fungal misellerin radyal gelişimleri ölçülmek suretiyle fungisitlerin misel gelişimini engelleme oranları (\%) belirlenmiştir (Uysal ve Kurt, 2019). Denemelerde her petri 1 tekerrür ve her konsantrasyon 3 tekerrür olacak şekilde tesadüf parselleri deneme desenine göre kurulmuştur. Deneme 2 farklı zamanda tekrar edilmiştir.

\section{Deneme deseni ve istatistik analizler}

In vitro denemeler tesadüf parselleri deneme desenine göre, her bir uygulama için 3 tekerrür olacak şekilde kurulmuştur. Farklı uygulamaların (farklı fungisit konsantrasyonları bulunduğu petrilerdeki antifungal etkinlik çalışmaları) yapıldığı petrilerdeki misel gelişiminin engellenme oranları \% oranlarına çevrilmeden SPSS istatistik programı (SPSS Statistics 17.0) kullanılarak tek yönlü ANOVA ile varyans analizi yapıımış ve uygulamalar arasındaki farklılık Duncan Çoklu Karşılaştırma Testi ile analiz edilmiştir $(P \leq 0.05)$. Fungisitlerin farklı konsantrasyonlarda misel gelişimini $\% 50$ düzeyinde engelleyen etkili konsantrasyonları $\left(\mathrm{EC}_{50}\right)$ her bir kimyasal için farklı konsantrasyonlarda elde edilen değerleri kullanılarak SPSS istatistik programı (Versiyon 11.5, SPSS Inc., Chicago, IL, USA) yardımı ile Probit analizi yapılarak belirlenmiştir.

\section{BULGULAR ve TARTIŞMA}

\section{Hastalık etmeninin izolasyonu}

Çalışmanın yapıldığı Hatay ilinin İskenderun ilçesinde 5 farklı ceviz bahçesinde yapılan incelemeler sonucunda, ceviz ağaçlarında genel bir gelişme geriliği, yapraklarda sararma şeklinde belirtiler gözlenmiştir. Ayrıca ağaçlarınn gövde kısımlarında sulanma, kahverengi akıntı, kabuğun dışa doğru kabarması, siğilleşme şeklinde lezyonlar kaydedilmiştir. Enfeksiyonun şiddetine göre ağaçların gövde kabuk dokusu gittikçe koyulaşmakta ve bu alanlarda sakızlanma oluşturduğu gözlenmiştir (Şekil 1).
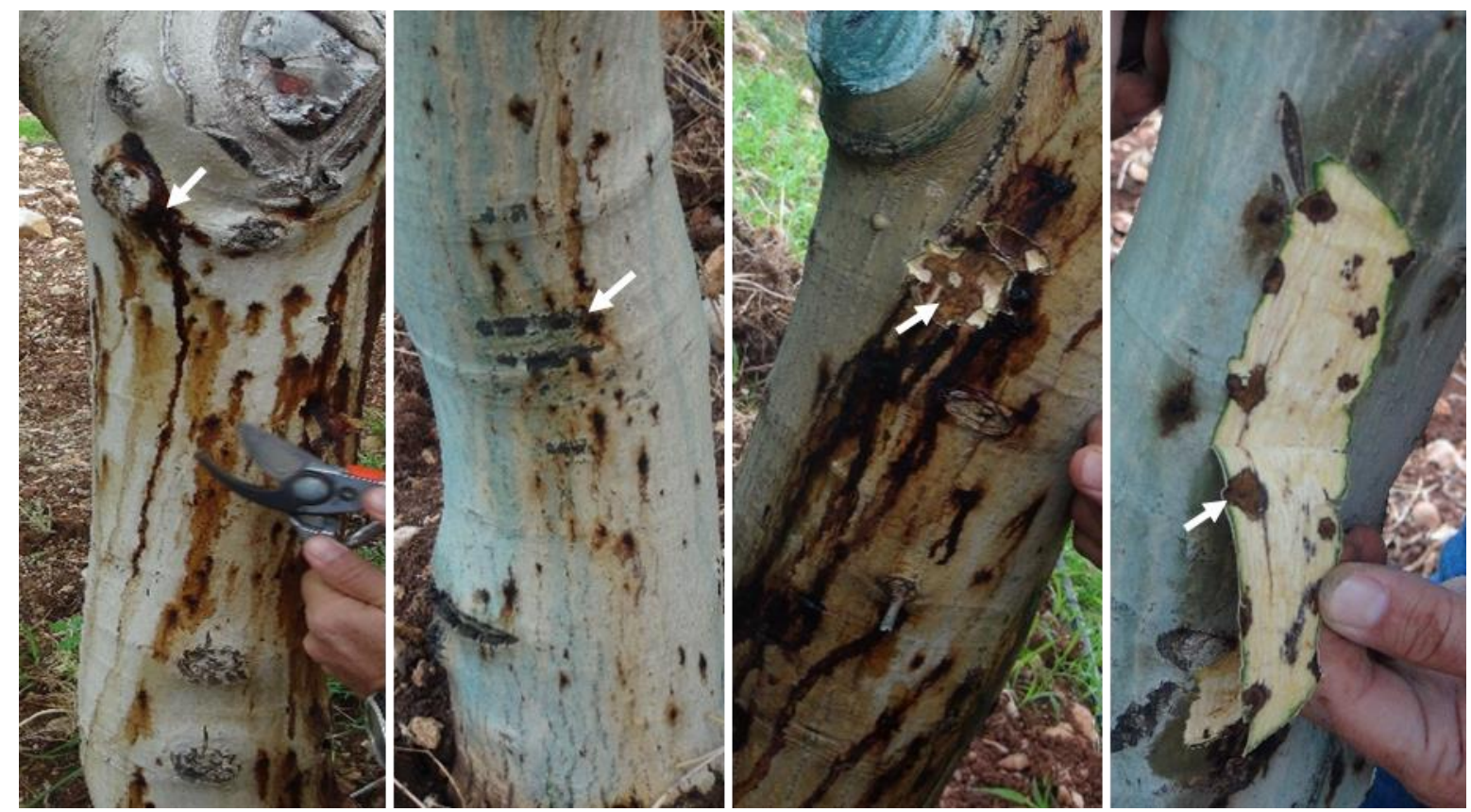

Şekil 1. Ceviz ağaçlarının (cv. Chandler) gövdelerinde Botryosphaeria enfeksiyonlarının neden olduğu tipik sulanma, kahverengi akıntı, kabuğun dışa doğru kabarması şeklinde ortaya çıkmış hastalık belirtileri (ok).

Bu tip hastalık belirtilerinin olduğu ceviz ağaçlarının gövde kesitlerinden yapılan izolasyonlar sonucunda zeytin yeşili- gri renkte kolonilere sahip 10 adet fungal izolat elde edilmiştir. Kaliforniya'nın 13 farklı alanında 
yetiştirilen İngiliz tipi ceviz ağaçlarında Botryosphaeriaceae ve Diaporthaceae familyasına dahil fungal etmenlerin filogenisi, morfolojisi, dağılımı ve patojenisitesi konusunda yapılan sörveylerde çalışmamızdaki belirtilere benzer şekilde, ceviz ağaçlarının gövde ve dallarında kanser belirtileri, meyvelerde yanıklık, yapraklarda ise nekrotik lezyonlar şeklinde karekterize edilmiş hastalık belirtilerinden aralarında $B$. dothidea'nında yer aldığı, Diplodia mutila, D. seriata, Dothiorella iberica, Lasiodiplodia citricola, Neofusicoccum mediterraneum, $N$. nonquaesitum, $N$. parvum, N. vitifusiforme, Neoscytalidium dimidiatum, Diaporthe neotheicola ve D. Rhusicola fungal hastalık etmenleri izole edildiği bildirilmiştir (Chen ve ark., 2014).

\section{Hastalık etmeninin morfolojik karakterizasyonu}

Hastalıklı bitkilerinden yapılan izolasyonlar sonucu elde edilen kültürlerde, PDA'da gelişen koloniler başlangıçta renksiz veya açık zeytin yeşili gri renkte olup, zamanla koyulaşmış ve siyah rengine dönüşmüştür (Şekil 2A ve B). Oluşan bu koloniler üzerinde piknidiumların meydana geldiği saptanmıştır. Mikroskobik incelemeler sonucunda konidilerin, fusiform şeklinde, şeffaf, pürüzsüz kalın duvarlı ve septasız yapıda olduğu belirlenmiştir (Şekil 2C ve D). Fusiform şeklindeki bu konidilerin boyutları ise 18.0-22.5 x 5.0-6.5 $\mu \mathrm{m}$ arasında olduğu kaydedilmiştir. Hastalıklı bitkilerden elde edilen izolatlara ait fungal yapıların morfolojik karakterlerine dayanarak elde edilen izolat, Botryosphaeria dothidea (Mougeot) Cesati \& de Notaris (Anamorph Fusicoccum aesculi Corda) olarak tanımlanmıştır (Qiu ve ark., 2008).
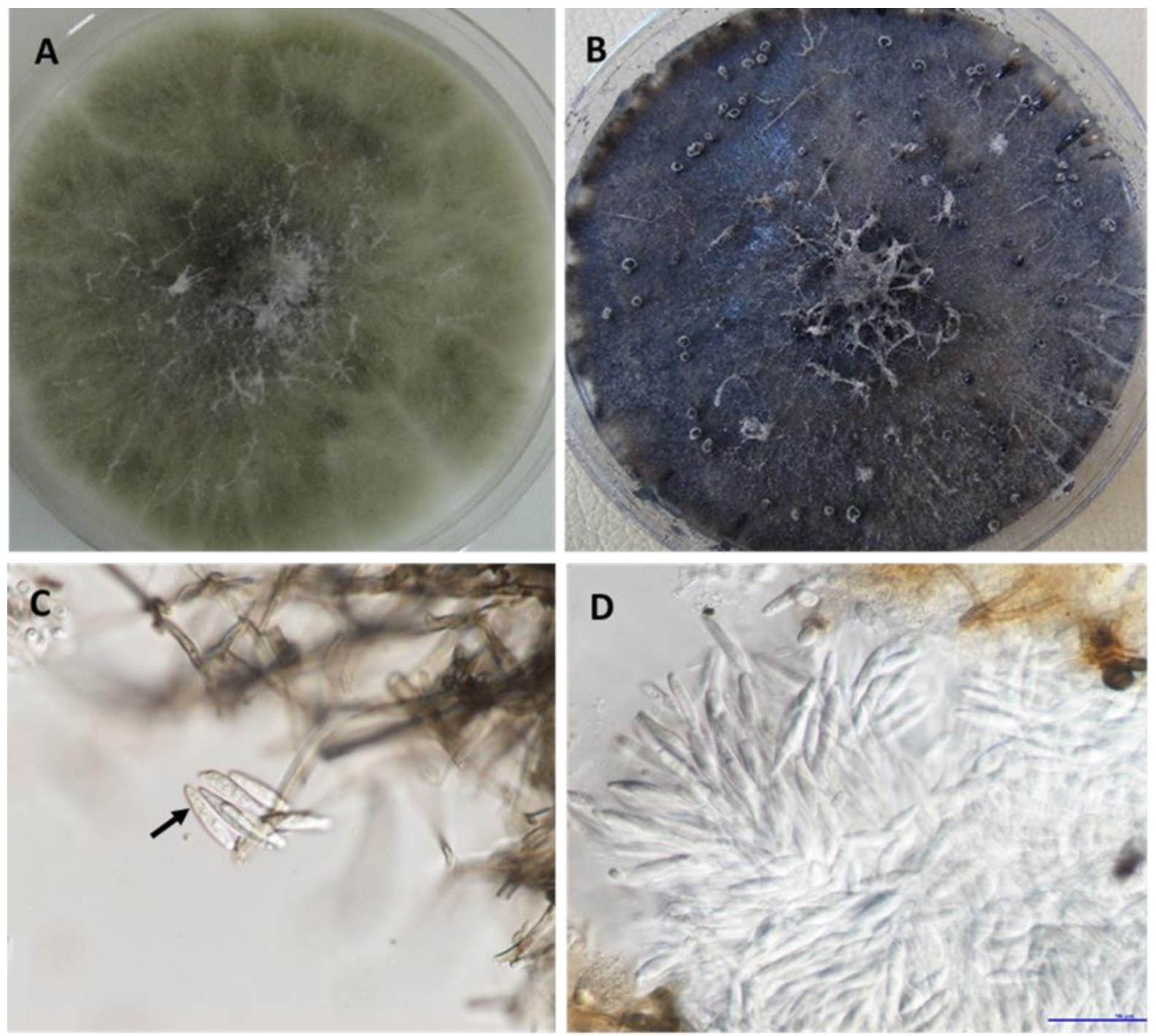

Şekil 2. Fungal etmen Botryosphaeria dothidea WBd31 izolatının PDA besi yerinde (A) 5 ve (B) 20 günlük miselyal gelişimleri. (C ve D) B. dothidea izolatına ait tipik konidileri (ok). 
Ayrıca morfo-kültürel olarak patojenin beş farklı besi ortamında 8 farklı sıcaklıkta yapılan çalışmada miselyal gelişim düzeyleri incelendiğinde, $20-30^{\circ} \mathrm{C}$ arasındaki sıcaklıklarda hemen hemen tüm besi ortamlarında fungusun maksimum gelişim gösterdiği kaydedilmiştir
(Çizelge 2). Hastalık etmeni fungus, en düşük $\left(5^{\circ} \mathrm{C}\right)$ ve en yüksek $\left(40^{\circ} \mathrm{C}\right)$ sıcaklıklarda herhangi bir koloni gelişimi göstermemiştir. Ayrıca, yüksek sıcaklıklarda gelişme gözlenmediği, fakat sıcaklıklar düştükçe az miktar da olsa gelişme olduğu kaydedilmiştir.

Çizelge 2: Farklı besi ortamları ve sıcaklıklarda B. dothidae WBd31 izolatının koloni çapları (mm).

\begin{tabular}{cccccc}
\hline \multirow{2}{*}{ Sıcaklık $\left({ }^{\circ} \mathbf{C}\right)$} & \multicolumn{5}{c}{ Besi ortamları ve koloni çapları $(\mathbf{m m})$} \\
\cline { 2 - 5 } & PDA & CDA & MEA & V8 & WA \\
\hline $\mathbf{5}$ & $0.0 \pm 0.0 \mathrm{aA}$ & $0.0 \pm 0.0 \mathrm{aA}$ & $0.0 \pm 0.0 \mathrm{aA}$ & $0.0 \pm 0.0 \mathrm{aA}$ & $0.0 \pm 0.0 \mathrm{aA}$ \\
$\mathbf{1 0}$ & $29.0 \pm 0.6 \mathrm{bC}$ & $15.3 \pm 0.5 \mathrm{bB}$ & $28.0 \pm 1.2 \mathrm{bC}$ & $41.3 \pm 1.3 \mathrm{bD}$ & $9.0 \pm 1.5 \mathrm{bA}$ \\
$\mathbf{1 5}$ & $63.0 \pm 1.5 \mathrm{cC}$ & $58.0 \pm 1.3 \mathrm{~dB}$ & $75.3 \pm 1.2 \mathrm{cD}$ & $73.0 \pm 1.1 \mathrm{dD}$ & $43.0 \pm 0.0 \mathrm{cA}$ \\
$\mathbf{2 0}$ & $80.0 \pm 0.0 \mathrm{dC}$ & $78.0 \pm 0.5 \mathrm{eB}$ & $80.0 \pm 0.0 \mathrm{eB}$ & $80.0 \pm 0.0 \mathrm{eC}$ & $43.0 \pm 0.0 \mathrm{cA}$ \\
$\mathbf{2 5}$ & $80.0 \pm 0.0 \mathrm{~dB}$ & $75.3 \pm 0.5 \mathrm{eA}$ & $80.0 \pm 0.0 \mathrm{eB}$ & $80.0 \pm 0.0 \mathrm{eB}$ & $80.0 \pm 0.0 \mathrm{fB}$ \\
$\mathbf{3 0}$ & $80.0 \pm 0.0 \mathrm{~dB}$ & $77.0 \pm 0.5 \mathrm{eB}$ & $80.0 \pm 0.0 \mathrm{eB}$ & $78.3 \pm 0.5 \mathrm{eB}$ & $64.0 \pm 0.0 \mathrm{eA}$ \\
$\mathbf{3 5}$ & $79.0 \pm 1.3 \mathrm{dD}$ & $42.0 \pm 1.2 \mathrm{cA}$ & $79.3 \pm 1.3 \mathrm{eE}$ & $52.0 \pm 1.1 \mathrm{cC}$ & $50.3 \pm 1.2 \mathrm{~dB}$ \\
$\mathbf{4 0}$ & $0.0 \pm 0.0 \mathrm{aA}$ & $0.0 \pm 0.0 \mathrm{aA}$ & $0.0 \pm 0.0 \mathrm{aA}$ & $0.0 \pm 0.0 \mathrm{aA}$ & $0.0 \pm 0.0 \mathrm{aA}$ \\
\hline
\end{tabular}

PDA: Patates Dektroz Agar, CDA: Czapek Dox Agar, MEA: Malt Extract Agar, V8: V8 Juice Agar, WA: Water Agar

* Satır ve sütun içinde yer alan ortalama koloni çaplarının ( $\mathrm{mm} \pm$ S.D) yanındaki sırasıyla farklı küçük ve büyük harfler uygulamalar arasındaki farkın istatistiksel olarak Duncan Çoklu Karşılaştırma Testine $(p \leq 0,05)$ göre önemli olduğunu gösterir.

\section{Patojenisite çalışmaları}

Patojenisite çalışması sonucunda $B$. dothidea WBd31 izolatı ile sağlıklı ceviz fidanlarından kesilen sürgünlere yapılan inokulasyondan 20 gün sonra odun dokularında kahverengi lezyonların oluşumu gözlenmiştir. Steril agar inokule edilen sürgünlerde ise herhangi bir lezyon oluşmadığı gözlenmiştir. Enfeksiyon gözlenen inokulasyon alanında lezyon uzunlukları, ortalama 55.0 $\mathrm{mm}$ olarak saptanmıştır. Bu çalışma sonucunda temsili olarak seçilen $B$. dothidea WBd31 izolatının patojen olduğu belirlenmiştir. Bu enfeksiyonlu alanlardan yapılan izolasyon sonucunda fungus tekrar izole edilebilmiştir. Li ve ark., 2016'da yaptıkları çalışmada, İngiliz cevizlerinden elde ettikleri kanser ve geriye doğru ölümlere neden olan Botryosphaeria dothidea and Lasiodiplodia pseudotheobromae etmenlerinin kesilmiş sağlıklı dallara yaptıkları patojenisite çalışmalarında her iki fungusu patojen olarak saptamışlardır. Chen ve ark., 2014'de Kaliforniya'da İngiliz cevizlerinde yaptıkları Botryosphaeriaceae ve Diaporthaceae türlerinin belirlenmesi çalışması kapsamında elde ettiklerin fungus türlerinin patojenisite çalışmalarında, miselyum disk yöntemi kullanılarak üç İngiliz ceviz çeşidine (Chandler, Tulare ve Vina) inokulasyon yapmışlardır. Inokulasyon sonrası Lasiodiplodia citricola ve Neofusicoccum parvum, Neofusicoccum mediterraneum, Neoscytalidium dimidiatum ve Botryosphaeria dothidea'ya kıyasla daha şiddetli hastalık belirtilerinin gelişmesine neden olduğunu bildirmişlerdir.

\section{Hastalık etmeninin moleküler karakterizasyonu}

Elde edilen fungal izolatlardan seçilen temsili $B$. dothidea WBd31 izolatının DNA izolasyonu sonucunda $20-40 \mathrm{ng} / \mu \mathrm{l}$ arasında değişen miktarda genomik DNA elde edilmiştir. PCR amplifikasyon çalışmaları ile çoğaltılan DNA ürünlerinden, ITS (ITS-1- ve ITS-4), TUB2 ( $\beta-2 a$ ve $\beta-2 b$ ) gen bölgelerine spesifik primerler kullanılmak suretiyle, sırasıyla 423 ve 433 bp büyüklüğünde bantlar elde edilmiştir. Nükleotid dizileri, GenBank veritabanında BLAST araştırması ile karşılaştırılmış ve GenBank veri tabanında önceden tanılaması yapılmış ve $B$. dothidea izolatlarına (ITS ve TUB gen bölgeleri için erişim numaraları, sırasıyla MK982843 ve MH791314) \%100 benzerlik göstermiştir. Çalışmamızda, morfolojik ve moleküler olarak tanılması yapılan $B$. dothidea WBd31 kodlu izolata ait nükleotid dizi sonuçları GenBank veritabanına yüklenerek erişim numarası alınmıştır (ITS geni için MN244276, TUB2 geni için MN244680). Nükleotid dizileri, Maksimum likelihood yöntemi kullanılarak MEGA 7 yazılımı ile ITS ve TUB 2 genleri için kombine edilerek dendrogram elde edilmiştir. Bu dendrograma göre $B$. dothidea WBd31 izolatı, Botryosphaeria dothidea GZHGS-2017-010 türü ile aynı alt grupta yer ayrılmıştır. Diaporthe rhusicola 6114 türü ise dış grup olarak belirlenmiştir (Şekil 3). 


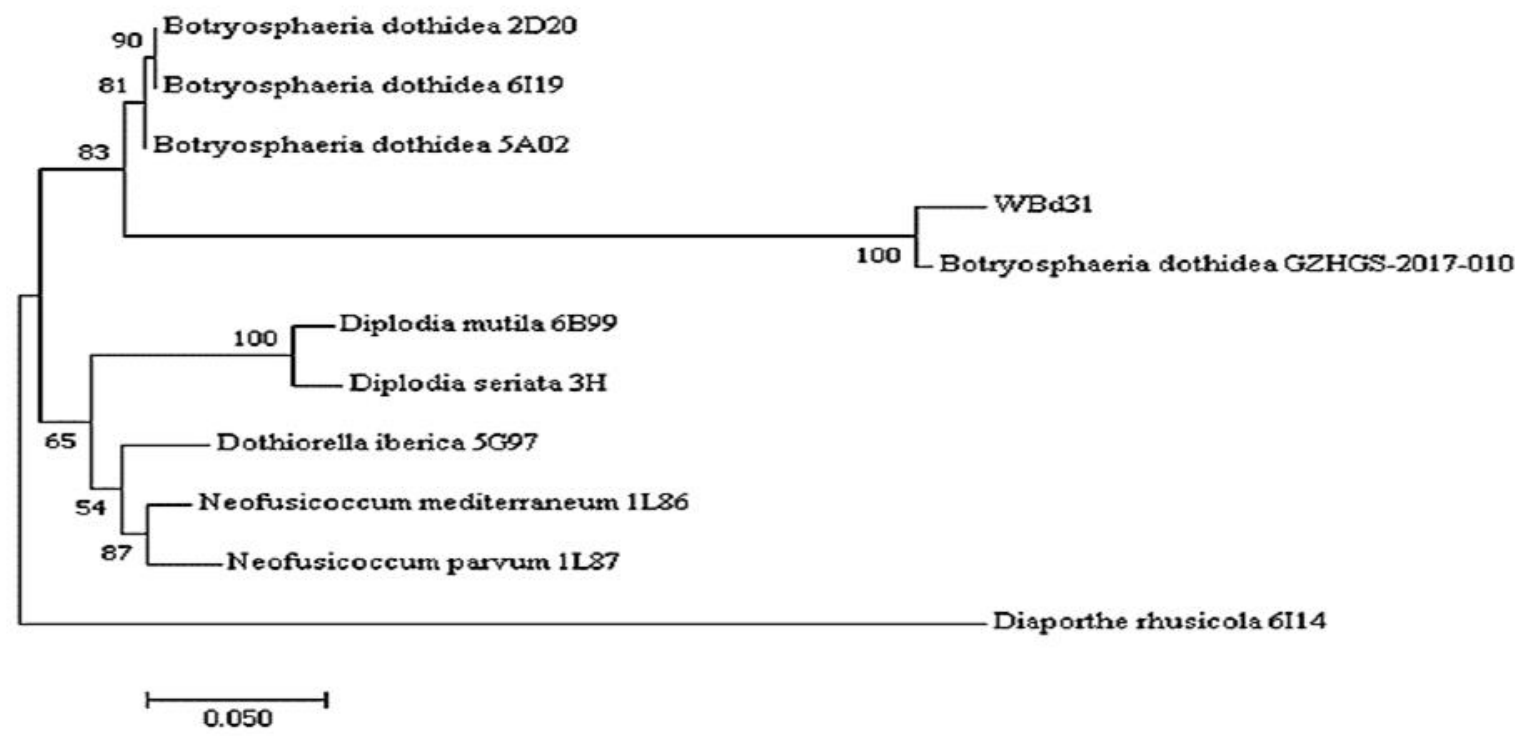

Şekil 3. B. dothidea WBd31 izolatının ITS ve TUB2 gen dizilerinin kombinasyonu ile oluşturulan dendrogram

Yapılan morfo-kültürel, patojenisite denemeleri ve moleküler analizler sonucu i̇skenderun ilçesinde yetiştirilen ceviz ağaçlarında kurumalara neden olan fungal etmenin Botryosphaeria dothidea olduğu kesinlik kazanmıştır. Yapılan kapsamlı literatür araştırmasında (Farr ve Rossman, 2020), hastalık etmeninin ülkemiz için cevizlerde söz konusu belirtilerden sorumlu fungal hastalık etmeni olduğu ilk kez bu çalışma ile belirlenmiştir.

Çin'deki İngiliz çeşidi cevizlerde Botryosphaeria dothidea ve Lasiodiplodia pseudotheobromae'nın karakterizasyonu şeklinde yapılan çalışmada ITS rDNA and translation elongation factor 1-alpha (TEF-1a) gen bölgelerine göre elde edilen izolatların Botryosphaeria dothidea and Lasiodiplodia pseudotheobromae olduğu moleküler olarak karakterize edilmiştir (Li ve ark., 2016). Chen ve ark., (2014), Kaliforniya'da İngiliz çeşidi cevizlerde Botryosphaeriaceae ve Diaporthaceae türlerinin belirlenmesi konusunda yaptıkları çalışma ile Botryosphaeriaceae'ya ait 10, Diaporthaceae'ya ait 2 farklı tür elde etmişlerdir. Bu türleri Botryosphaeria dothidea, Diplodia mutila, D. seriata, Dothiorella iberica, Lasiodiplodia citricola, Neofusicoccum mediterraneum, $N$. nonquaesitum, $N$. parvum, $N$. vitifusiforme, Neoscytalidium dimidiatum, Diaporthe neotheicola and D. rhusicola olarak tanımlamışlarıdır. Luo ve ark. (2017), Kaliforniya eyaletinde yetişen kabuklu sert çekirdekli meyve ağaçlarındaki kurumalara Botryosphaeria dothidea türünün yanısıra, Cytospora, Diplodia, Lasiodiplodia, Neofusicoccum ve Phomopsis spp. türlerine ait fungal etmenlerin neden olduğunu belirlemişlerdir. Söz konusu bölgede yapılan detaylı sörvey ve tanılama çalışmaları (Luo ve ark., 2019) sonucunda; bu etmenlerden Phomopsis ve Diplodia spp. düşük, $B$. dothidea ve Lasiodiplodia spp. yüksek ve Neofusicoccum spp. ise orta düzeyde yaygınlık gösterdiğini bildirmişlerdir. Sonuçta 6 farklı etmenin genel durumu değerlendirildiğinde, Phomopsis ve Diplodia spp. bölgede kanser hastalıkları arasında düşük öneme sahipken, Lasiodiplodia spp. en saldırgan ve iyi gelişen populasyon, Cytospora spp. 1-2 erik bahçesinde baskın tür olduğu, B. dothidea ve Neofusicoccum spp.'nin bölgede farklı meyve ağaçlarında yüksek yaygınlık eğilimi gösteren hastalıklar olarak değerlendirilmiştir (Luo ve ark., 2019).

Hastalık etmenin ülkemizde varlığı farklı bölgelerde yetişen bağlarda (Akgül ve ark., 2014; Akgül ve ark., 2015) ve elma ağaçlarında (Türkölmez ve ark., 2016) kurumalara neden olduğu önceden yapılan çalışmalarda da bildirilmiştir. California dışında, söz konusu hastalık etmeninin Çin (Li ve ark., 2016), İran (Abdollahzadeh ve ark., 2013) ve İspanya'da (Lopez-Moral ve ark., 2020) yetiştiriciliği yapılan ceviz ağaçlarında hastalığa neden olduğu bildirilmiştir.

\section{Hastalık etmeninin in vitro koşullarda fungisitlere karşı duyarlıı̆ı̆ın belirlenmesi}

Farklı fungisitlerin $B$. dothidea WBd31 izolatının misel gelişimini engelleyen antifungal etkileri incelendiğinde, hastalık etmeninin kresoxim-methyl hariç diğer fungisitlere karşı oldukça duyarlı olduğu gözlenmiştir. Denemede yer alan farklı kimyasal yapıdaki fungisitler arasında en yüksek etkinliği (\%100), $0.01 \mu \mathrm{g} / \mathrm{ml}$ konsantrasyonda fluazinam göstermiştir. Denemedeki her bir fungisitin hastalık etmeninin misel gelişimini \%50 oranında engellenmesi için gereken etkili konsantrasyon 
$\left(E_{50}\right)$ değerleri, Probit analizi ile belirlenmiştir. Elde edilen sonuçlara göre, en düşük $\mathrm{EC}_{50}$ değeri $0.002 \mu \mathrm{g} / \mathrm{ml}$ ile en yüksek fungisidal etkinlik gösteren ilaç fluzinam olarak kaydedilirken, bu fungisiti $0.275 \mu \mathrm{g} / \mathrm{ml}$ ile thiophanate-methyl, $0.994 \mu \mathrm{g} / \mathrm{ml}$ ile tebuconazole, $3.993 \mu \mathrm{g} / \mathrm{ml}$ ile boscalid+pyraclostrobin, $4.262 \mu \mathrm{g} / \mathrm{ml}$ ile trifloxystrobin etken maddeli fungisitler takip etmiştir. Fungisitler arasında en düşük etkinlik ise, $55.246 \mu \mathrm{g} / \mathrm{ml}$ ile en yüksek $\mathrm{EC}_{50}$ değerine sahip kresoxim methyl tarafından ortaya konmuştur (Çizelge 3). Sonuç olarak çalışmada kullanılan fungisitler içerisinde fluazinam, thiophanate-methyl ve tebuconazole düşük $\mathrm{EC}_{50}$ değerleri ile Botryosphaeria dothidea WBd31 izolatına karşı en etkili fungisitler olarak belirlenmiştir.

Çizelge 3 Farklı konsantrasyonlarda kullanılan bazı fungisitlerin in vitro koşullarda Botryosphaeria dothidea izolatının misel gelişiminin engellenmesi üzerine olan antifungal etkileri

\section{Fungisitler ve uygulama dozları $(\mu \mathrm{g} / \mathrm{ml})^{\mathrm{a}}$}

\begin{tabular}{|c|c|c|c|c|c|c|c|}
\hline \multirow[b]{3}{*}{ Kontrol } & \multicolumn{6}{|c|}{ Fungisitler ve uygulama dozları $(\mu \mathrm{g} / \mathrm{ml})^{\mathrm{a}}$} & \multirow[b]{3}{*}{$\mathrm{EC}_{50}{ }^{\mathrm{b}}$} \\
\hline & \multicolumn{6}{|c|}{ Trifloxystrobin } & \\
\hline & 0.5 & 1.0 & 5.0 & 10.0 & 20.0 & 50.0 & \\
\hline $80 \pm 0.0 f *$ & $65.0 \pm 3.6 e$ & $55.0 \pm 3.6 d$ & $43.3 \pm 2.3 c$ & $28.0 \pm 2.6 b$ & $18.3 \pm 2.52 \mathrm{a}$ & $14.0 \pm 2.0 \mathrm{a}$ & 4.262 \\
\hline \multicolumn{8}{|c|}{ Tebuconazole } \\
\hline Kontrol & 0.5 & 1.0 & 5.0 & 10.0 & 20.0 & 50.0 & \\
\hline $80.0 \pm 0.0 \mathrm{~g}$ & $48.0 \pm 2.6 f$ & $35.0 \pm 2.0 \mathrm{e}$ & $28.33 \pm 3.5 d$ & $20.3 \pm 3.2 c$ & $9.33 \pm 1.5 b$ & $4.3 \pm 0.6 a$ & 0.994 \\
\hline \multicolumn{8}{|c|}{ Thiophanate-methyl } \\
\hline Kontrol & 0.1 & 0.5 & 1.0 & 3.0 & 5.0 & 10.0 & \\
\hline $80.0 \pm 0.0 \mathrm{~g}$ & $54.0 \pm 2.6 f$ & $30.0 \pm 2.7 e$ & $22.0 \pm 2.6 \mathrm{~d}$ & $13.3 \pm 2.3 c$ & $7.3 \pm 1.5 b$ & $0.0 \pm 0.0 \mathrm{a}$ & 0.275 \\
\hline \multicolumn{8}{|c|}{ Fluazinam } \\
\hline Kontrol & 0.001 & 0.003 & 0.005 & 0.007 & 0.01 & 0.015 & \\
\hline $80.0 \pm 0.0 f$ & $59.0 \pm 3.0 \mathrm{e}$ & $43.0 \pm 2.6 \mathrm{~d}$ & $23.3 \pm 2.5 c$ & $12.0 \pm 1.7 \mathrm{~b}$ & $0.0 \pm 0.0 a$ & $0.0 \pm 0.0 \mathrm{a}$ & 0.002 \\
\hline \multicolumn{8}{|c|}{ Kresoxim-methyl } \\
\hline Kontrol & 0.1 & 0.5 & 1.0 & 5.0 & 10.0 & 50.0 & \\
\hline $80.0 \pm 0.0 f$ & $74.3 \pm 2.5 \mathrm{e}$ & $63.3 \pm 2.6 \mathrm{~d}$ & $56.0 \pm 3.0 c$ & $51.0 \pm 3.0 \mathrm{~b}$ & $50.0 \pm 3.6 b$ & $44.33 \pm 3.1 a$ & 55.246 \\
\hline \multicolumn{8}{|c|}{ Boscalid+ pyraclostrobin } \\
\hline Kontrol & 1.0 & 3.0 & 5.0 & 10.0 & 20.0 & 50.0 & \\
\hline $80.0 \pm 0.0 \mathrm{~g}$ & $64.3 \pm 2.5 f$ & $50.3 \pm 2.5 e$ & $31.0 \pm 3.0 \mathrm{~d}$ & $22.0 \pm 2.0 \mathrm{c}$ & $12.3 \pm 1.5 b$ & $5.0 \pm 1.7 a$ & 3.993 \\
\hline
\end{tabular}

a Satır içinde yer alan ortalama koloni çaplarının ( $\mathrm{mm} \pm$ S.D) yanındaki farklı harfler uygulamalar arasındaki farkın istatistiksel olarak Duncan Çoklu Karşılaştırma Testine göre önemli olduğunu gösterir $(P<0.05)$.

b Fungisitlerin misel gelişimini \%50 düzeyinde engelleyen etkili konsantrasyonları (EC50) her bir fungisit için farklı konsantrasyonlarda elde edilen değerleri kullanılarak SPSS istatistik programı (Versiyon 17.0, SPSS Inc., Chicago, IL, USA) yardımı ile Probit analizi yapılarak tahmin edilmiştir.

Ülkemizde ve dünyada ceviz kanser hastalıklarının kimyasal mücadelesi üzerine yapılmış çalışmaların oldukça kısıtlı düzeyde olduğu gözlenmektedir. Avustralya'da bağlarda Botryosphaeria kanserinin mücadelesinde fungisitlerin etkileri, $B$. dothidea, Neofusicoccum parvum, Lasiodiplodia theobromae ve Diplodia seriata türlerine karşı 20 farklı fungisitinin in vitro denemeleri ile ortaya konmuştur. $\mathrm{EC}_{50}$ değeri $<1.0$ $\mathrm{mg} / \mathrm{l}$ 'nin altında olan fludioxonil, carbendazim, fluazinam, tebuconazole, flusilazole, penconazole, procymidone, iprodione, myclobutanil ve pyraclostrobin, en etkili fungisitler olarak belirlenmiştir (Pitt ve ark., 2012). Ayrıca, Urbez-Torres ve ark. (2013), Şili'deki bağ alanlarında yaygın olarak kullanılan DMI grubu fungisitlerin Diplodia ve Neofusicoccum türlerinin miseliyal gelişimine etkisini belirlemek için yaptıkları çalışmada, D. mutila, $D$. seriata, $N$. australe ve $N$. parvum patojenlerine tebuconazole, myclobutanil, prochloraz, prochloraz+epoxiconazole fungisitlerinin etkinliğinin oldukça yüksek olduğunu saptanmışlardır. 
Sonuç olarak, Hatay ili İskenderun ilçesinde yetiştiriciliği yapılan cevizlerde gövde kanseri hastalık belirtilerine neden olan hastalık etmeni, morfolojik, patolojik ve moleküler çalışmaları sonucunda Botryosphaeria dothidea olarak tanılanmıştır. Yapılan literatür araştırmasına göre, ülkemizde Botryosphaeria dothidea'nın ceviz ağaçalarında hastalık oluşturduğu ilk kez bu çalışma ile ortaya konulmuştur. Hastalık etmenine karşı farklı kimyasal yapıdaki fungisitlerin etkinlikleri in vitro koşullarda belirlendiği çalışma sonuçlarına göre fungisitler içerisinde fluazinam, thiophanate-methyl ve tebuconazole düşük $\mathrm{EC}_{50}$ değerleri ile Botryosphaeria dothidea WBd31 izolatına karşı en etkili fungisitler olarak tespit edilmiştir.

\section{ÖZET}

Amaç: Çalışmada Hatay'ın İskenderun ilçesinde Mayıs 2019 tarihinde ceviz bahçelerdeki ceviz ağaçlarında, iletim dokularında kahverengi-koyu kahverengi renk değişikliği, odun dokusu nekrozu ve dallarda geriye doğru ölüm hastalık belirtilerine neden olan fungal etmenin tanılanması ve etmenin bazı fungisitlere karşı duyarlılık düzeylerinin belirlenmesi amaçlanmıştır.

Yöntem ve Bulgular: Hastalıklı dallardan, kanserlerden ve belirti göstermeyen ceviz örneklerinden yapılan izolasyonlar sonucunda elde edilen fungal izolat morfolojik ve moleküler çalışmalara göre Botryosphaeria dothidea olarak tanılanmıştır. Patojenisite denemeleri, fungal izolatın bölgede yetiştirilen Chandler çeşidi ceviz ağacı sürgünlerinde oldukça virülent olduğunu göstermiştir. Mevcut bilgilerimize göre bu çalışma, Türkiye'de cevizi enfekte eden Botryosphaeria dothidea'nın ilk raporudur. Fluazinam (0.001-0.015 $\mu \mathrm{g} / \mathrm{ml})$, thiophanate-methyl $(0.1-10.0 \mu \mathrm{g} / \mathrm{ml})$, boscalid + pyraclostrobin (1.0-50.0 $\mu \mathrm{g} / \mathrm{ml})$, trifloxystrobin (0.5-50.0 $\mu \mathrm{g} / \mathrm{ml})$, kresoxim-methyl $(0.1-50.0 \mu \mathrm{g} / \mathrm{ml})$ ve tebuconazole $(0.5-50.0 \mu \mathrm{g} / \mathrm{ml})$ gibi 6 farklı fungisitin farklı konsantrasyonlarının, fungal etmene karşı in vitro antifungal etkileri belirlenmiştir. Fungisitlerin ortalama etkili konsantrasyon $\left(E_{50}\right)$ değerleri, Probit analiziyle belirlenmiştir. Hesaplanan $\mathrm{EC}_{50}$ değerlerine göre hastalık etmenine karşı en etkili fungisit fluazinam $(0.002 \mu \mathrm{g} / \mathrm{ml})$ olarak kaydedilmiş olup, bu fungisiti thiophanate-methyl $(0.275 \mu \mathrm{g} / \mathrm{ml})$, tebuconazole $(0.994 \mu \mathrm{g} / \mathrm{ml})$, boscalid + pyraclostrobin $(3.993 \mu \mathrm{g} / \mathrm{ml})$ ve trifloxystrobin $(4.262$ $\mu \mathrm{g} / \mathrm{ml}$ ) izlemiştir. En düşük antifungal etkinlik fungisitler arasında misel gelişimini \%37.5 oranında engelleyen kresoxim-methyl tarafından gösterilmiştir.

Genel Yorum: Bu çalışma fungal etmen Botryosphaeria dothidea'nın Türkiye'de yetiştirilen ceviz ağaçlarında gövde kanseri hastalığa neden olduğunun ilk kayıdıdır.
Elde edilen sonuçlar ayrıca Botryosphaeria dothidea'nın sebep olduğu ceviz kanser hastalığının seçilen fungisitlerin uygulanmasıyla ağaçların hastalıktan korunabileceğini önermektedir.

Çalışmanın Önemi ve Etkisi: Sonuç olarak, fluazinam, thiophanate-methyl ve tebuconazole'ün fungal patojen B. dothidea'nın kontrolünde kullanım potansiyeli bulunduğunu ortaya koymaktadır.

Anahtar Kelimeler: Ceviz, Fungisit, Botryosphaeria dothidea, Botryosphaeriaceae.

\section{TEŞEKKÜR}

Bu çalışma, Hatay Mustafa Kemal Üniversitesi Bitki Sağlığı Kliniği Uygulama ve Araştırma Merkezi laboratuvarlarında gerçekleştirilmiştir.

\section{ÇIKAR ÇATIŞMA BEYANI}

Yazar(lar) çalışma konusunda çıkar çatışmasının olmadığını beyan eder.

\section{ARAŞTIRMACILARIN KATKI ORANI BEYANI}

Yazarlar çalışmaya eşit oranda katkı sağlamış olduklarını beyan eder.

\section{KAYNAKLAR}

Abdollahzadeh J, Zare R, Phillips AJL (2013) Phylogeny and taxonomy of Botryosphaeria and Neofusicoccum species in Iran, with description of Botryosphaeria scharifii sp. nov. Mycologia 105: 210-220.

Akgul DS, Savas NG, Eskalen A (2014) First report of wood canker caused by Botryosphaeria dothidea, Diplodia seriata, Neofusicoccum parvum, and Lasiodiplodia theobromae on grapevine in Turkey. Plant Dis. 98: 568.

Akgul DS, Savas, NG, Teker T, Keykubat B, Mayorquin JS, Eskalen A (2015) Fungal trunk pathogens of Sultana seedless vineyards in Aegean region of Turkey. Phytopathol. Medit. 54(2): 380-393.

Anonim (2017) FAOSTAT, Word Production Data. http://www.fao.org/faostat/en/\#data/QC/visualize (Erişim Tarihi: 28.12.2019)

Anonim (2018) TUiK Bitkisel Üretim İstatistikleri. https://biruni.tuik.gov.tr/medas/?kn=92\&locale=tr (Erişim Tarihi: 28.12.2019)

Arzanlou M, Moshari S, Bakhshi M, Khodaie S (2012) Botryosphaeria dothidea associated with grapevine decline disease in Iran. Australas. Plant Dis. Notes 7: 197-200.

Barr ME (1987) Prodromus to Class Loculoascomycetes. Hamilton I. Newell, Inc., Amherst, MA. 
Boratyn GM, Camacho C, Cooper PS, Coulouris G, Fong A, Ma N, Madden TL, Matten WT, McGinnis SD, Merezhuk Y, Raytselis Y, Sayers EW, Tao T, Ye J, Zaretskaya I (2013) BLAST: a more efficient report with usability improvements. Nucleic Acids Res. 41: 29-33.

Boriss H, Brunke H, Kreith M (2006) Commodity profile: English walnuts. Agricultural Issues Center, University of California, Davis.

Chen SF, Morgan D, Hasey JK, Anderson K, Michailides T (2014) Phylogeny, morphology, distribution, and pathogenicity of Botryosphaeriaceae and Diaporthaceae from English walnut in California. Plant Dis. 98: 636-652.

Damm U, Crous PW, Fourie PH (2007) Botryosphaeriaceae as potential pathogens of Prunus species in South Africa, with descriptions of Diplodia africana and Lasiodiplodia plurivora sp. nov. Mycologia 99(5): 664-680.

Derviş S, Türkölmez Ş, Çiftçi O, Ulubaş Serçe Ç, Dikilitaş M (2019) First report of Neoscytalidium dimidiatum causing black canker and root rot of walnut in Turkey. Plant Dis. 103(8): 2129.

Farr DF, Rossman AY (2020) Fungal databases. Systematic mycology and microbiology laboratory, USDA ARS. Retrieved from http://nt.arsgrin.gov/fungaldatabases/ (Erişim Tarihi: 27.12.2019)

Glass NL, Donaldson GC (1995) Development of primer sets designed for use with the PCR to amplify conserved genes from filamentous ascomycetes. Appl. Environ. Microbiol. 61: 1323-1330.

Inderbitzin P, Bostock RM, Trouillas FP, Michailides TJ (2010) A six locus phylogeny reveals high species diversity in Botryosphaeriaceae from California almond. Mycologia 102: 1350-1368.

Kumar S, Stecher G, Tamura K (2016) MEGA7: Molecular evolutionary genetics analysis version 7.0 for bigger datasets. Mol. Evolut. Genetics Analysis 33(7): 18701874.

Li GQ, Liu FF, Li JQ, Liu QL, Chen SF (2016) Characterization of Botryosphaeria dothidea and Lasiodiplodia pseudotheobromae from English walnut in China. J. Phytopathol. 164(5): 348-353.

Lopez-Moral A, Lovera M, del Carmen Raya M, CortesCosano N, Arquero O, Trapero A, Agusti-Brisach C (2020) Etiology of branch dieback and shoot blight of english walnut caused by Botryosphaeriaceae and Diaporthe species in Southern Spain. Plant Dis. 104(2): 533-550
Luo Y, Gu S, Felts D, Puckett RD, Morgan DP, Michailides TJ (2017) Development of qPCR systems to quantify shoot infections by canker-causing pathogens in stone fruits and nut crops. J. Appl. Microbiol. 122(2): 416-428.

Luo Y, Lichtemberg PSF, Niederholzer FJA, Lightle DM, Felts DG, Michailides TJ (2019) Understanding the process of latent infection of canker-causing pathogens in stone fruit and nut crops in California. Plant Dis. 103(9): 2374-2384.

Ma Z, Michailides TJ (2002) Characterization of Botryosphaeria dothidea isolates collected from pistachio and other plant hosts in California. Phytopathology 92: 519-526.

McDonald V, Lynch S, Eskalen A (2009) First report of Neofusicoccum australe, $N$. luteum and $N$. parvum associated with avocado branch canker in California. Plant Dis. 93: 967.

McDonald V, Eskalen A (2011) Botryosphaeriaceae species associated with avocado branch cankers in California. Plant Dis. 95: 1465-1473.

Michailides TJ (1991) Pathogenicity, distribution, sources of inoculum, and infection courts of Botryosphaeria dothidea on pistachio. Phytopathology 81: 566-573.

Moral J, Muñoz-Díez C, González N, Trapero A, Michailides TJ (2010) Characterization and pathogenicity of Botryosphaeriaceae species collected from olive and other hosts in Spain and California. Phytopathology 100: 1340-1351.

Nouri MT, Lawrence DP, Holland LA, Doll DA, Kallsen CE, Culumber CM, Trouillas FP (2019) Identification and pathogenicity of fungal species associated with canker diseases of pistachio in California. Plant Dis. 103(9): 2397-2411.

Pitt WM, Sosnowski MR, Huang R, Qiu Y, Steel CC, Savocchia S (2012) Evaluation of fungicides for the management of Botryosphaeria canker of grapevines. Plant Dis. 96: 1303-1308.

Qiu Y, Savocchia S, Steel CC, Ash GJ (2008) Botryosphaeria dothidea associated with grapevine trunk disease in south-eastern Australia. Australas. Plant Pathol. 37: 482-485.

Slippers B, Wingfield MJ (2007) Botryosphaeriaceae as endophytes and latent pathogens of woody plants: diversity, ecology and impact. Fung. Biol. Rev. 21: 90106.

Turkolmez S, Dervis S, Ciftci O, Serce CU (2016) First report of canker and dieback caused by Botryosphaeria dothidea on apple in Turkey. Plant Dis. 100(6): 1237-1238. 
Úrbez-Torres JR, Leavitt GM, Voegel TM, Gubler WD (2006) Identification and distribution of Botryosphaeria spp. associated with grapevine cankers in California. Plant Dis. 90: 1490-1503.

Úrbez-Torres JR, Gubler WD (2009) Pathogenicity of Botryosphaeriaceae species isolated from grapevine cankers in California. Plant Dis. 93: 584-592.

Úrbez-Torres JR, Peduto F, Vossen PM, Krueger WH, Gubler WD (2013) Olive twig and branch dieback: etiology, incidence, and distribution in California. Plant Dis. 97: 231-244.
Uysal A, Kurt Ş (2019) Limonda antraknoz hastalığı etmeni Colletotrichum gloeosporioides (Penz.) Penz. \& Sacc.'in bazı fungisitlere karşı in vitro duyarlılığı. Bitki Koruma Bülteni 59(1): 53-62.

White TJ, Bruns T, Lee S, Taylor J (1990) Amplification and direct sequencing of fungal ribosomal RNA genes for phylogenetics. In: Innis MA, Gelfand DH, Sninsky JJ, White TJ (eds) In: PCR Protocols: A Guide to Methods and Applications. Academic Press, San Diego, pp. 315-322. 